\title{
The lichens and allied fungi of forest rocky communities of the Vysokaya (Volda) Mountain (Windy Belt Ridge, Arkhangelsk Region, NW Russia)
}

\author{
Viktoria N. Tarasova ${ }^{1}$, Angella V. Sonina ${ }^{1}$, Vera I. Androsova ${ }^{1}$, \\ Andrei A. Valekzhanin ${ }^{2}$, Liudmila A. Konoreva ${ }^{3,4}$ \\ ${ }^{1}$ Department of Botany and Plant Physiology, Petrozavodsk State University, 33 Lenin str., 185910 Petrozavodsk, Russia. \\ E-mails: tarasova1873@gmail.com, vera.androsova28@gmail.com, angella_sonina@mail.ru \\ ${ }^{2}$ N. Laverov Federal Center for Integrated Arctic Research RAS (FCIARctic), Severnoy Dviny Embankment, 23, 163000 \\ Arkhangelsk, Russia. E-mail: valekzhanin13@gmail.com \\ ${ }^{3}$ Polar-alpine Botanical Garden-Institute, 184250 Kirovsk, Murmansk Region, Russia. E-mail: ajdarzapov@yandex.ru \\ ${ }^{4}$ Laboratory of Lichenology and Bryology, Komarov Botanical Institute of RAS, 2 Professor Popov str.,
}

197376 St. Petersburg, Russia

\begin{abstract}
The paper presents the results of continuing research of lichen diversity in rocky communities of Windy Belt Ridge (Arkhangelsk Region, NW Russia). Using the method of sample plots and linear routes, the communities of the mountain Vysokaya (Volda) were examined, and 270 species and 2 subspecies of lichens and allied fungi were recorded there. A total of 18 lichens are new for the mainland area of Arkhangelsk Region, 35 species are new to the Vodlozersky National Park (Arkhangelsk part) and 9 species are in the Red Data Book of Arkhangelsk Region (2020). Within sample plots (altogether $0.2 \mathrm{ha}), 230$ species were found, with $41-50 \%$ of total species number being presented within one sample plot $(0.04 \mathrm{ha})$. Along the linear route $(2 \mathrm{~km}), 190$ taxa were recorded: 43 species were found only on the route (outside the sample plots), which is $16 \%$ of the total lichen species number in studied communities. Comparative analysis of the lichen diversity between currently studied mountains (Olovgora, Muroigora, Vysokaya) of the Windy Belt Ridge showed that the high degree of community conservation, rocky type of communities with significant rocky outcrops, as well as landscape heterogeneity determine conditions for a high species diversity of lichens. In total, 343 species of lichens and allied fungi have been found for the studied mountains of the Windy Belt Ridge.
\end{abstract}

Keywords: lichen diversity, rocky communities, old-growth forests, Vysokaya, Volda, Vodlozersky National Park, Arkhangelsk Region

\section{INTRODUCTION}

The low-mountain Vetreny Poyas Ridge (in engl. Windy Belt) is an elevation that was discovered by the geographer M. N. Karbasnikov relatively recently, in 1928, and represents the edge of Baltic shield and transition zone to European Plain. Moreover, continental watershed between Atlantic (the Baltic Sea) and the Arctic Ocean (the White Sea) lies along the Windy Belt Ridge. The slopes of the ridge are covered with rocky forest communities, which are typical for Fennoscandia and unique for the Arkhangelsk Region, which is mostly located within a plain covered with thick Quaternary sediments. The junction of floras from the west and east, from the south and north in this area, the heterogeneity of the conditions on the slopes of the ridge as well as the altitude gradient and the proximity of the sea determine interest in studying biodiversity including lichens in this territory.
In addition, the rocky forest communities of the most hills of the ridge were not affected by the anthropogenic factor and therefore represent the communities that have existed for a long time since the last disturbances (fires) and rare key biotopes for the conservation of many species.

Continued lichen inventories are necessary to increase knowledge about the biodiversity of such an reference area with high conservation value communities. The lichen studies on the ridge Windy Belt began recently, nonetheless, they have revealed a high species diversity (269) of lichens and allied fungi in this area (Tarasova et al., 2015, 2016). For example, the oceanic lichen Platismatia norvegica was found on the ridge top (Olovgora Mountain) for the first time for the territory of the European part of Russia (Tarasova, 2014). For the territory of Arkhan- 
gelsk Region, the species Bryoria bicolor was reported only twice and all findings were from Windy Belt area (Olovgora and Vysokaya Mountains) (Tarasova et al., 2015, 2019). Nowadays, these species are listed in the Red Data Book of the Arkhangelsk Region (2020). However, the most part of the Windy Belt Ridge is not currently protected, while its rocky outcrops will be of interest to the mining industry.

This study continues the investigation of the lichen diversity in the Windy Belt Ridge. The present study focuses on the diversity of lichens and allied fungi in forest rocky communities of Vysokaya Mountain (former name - Volda Mountain). Vysokaya is the only protected mountain of the Windy Belt Ridge, because it is located within the territory of Vodlozersky National Park. The aim of the study was to enrich knowledge of the species diversity of the Arkhangelsk Region, which still remains poorly studied in comparison with neighbor territories (Tarasova et al., 2019), as well as to contribute to the list of lichen species of Vodlozersky National Park.

\section{MATERIALS AND METHODS}

The study area is located in the north-western part of the Arkhangelsk Region in northern area of Vodlozersky National Park (Fig. 1), about 42 $\mathrm{km}$ from the coastline of Onega Bay of the White Sea within Windy Belt Ridge (Vetreny Poyas). The height of mountain Vysokaya is $318 \mathrm{~m}$ a.s.1.

The physiogeographic and climatic characteristics of this area were described in detail in our previous papers (Tarasova et al., 2015; 2016).

The field work was carried out by the first four authors during expedition in June 2018. Specimens were collected in different types of rocky forest communities with time-since-last disturbance more than 300 years. The top and slopes of the mountain Vysokaya are covered mainly by spruce forests of Vaccinium myrtillus-feather mosses type. At the foot of the hill spruce swamp forest of Sphagnum mosses type occurred. The main phorophytes for listed lichens were spruce (Picea obovata Ledeb. \& Picea abies (L.) Karst.), birch (Betula pubescens Ehrh.), aspen (Populus tremula L.), rowan (Sorbus aucuparia L.), willow (Salix caprea L.) and pine (Pinus sylvestris L.). A total of 5 sample plots of $20 \times 20 \mathrm{~m}$ were established along a transect on the south-eastern slope of the mountain Vysokaya. A detailed geobotanical description of the rocky forest community was made for each sample plot including tree properties (height, age, basal area, crown density etc.) and the ground cover characteristics (shrub and herb cover, mosses and lichen

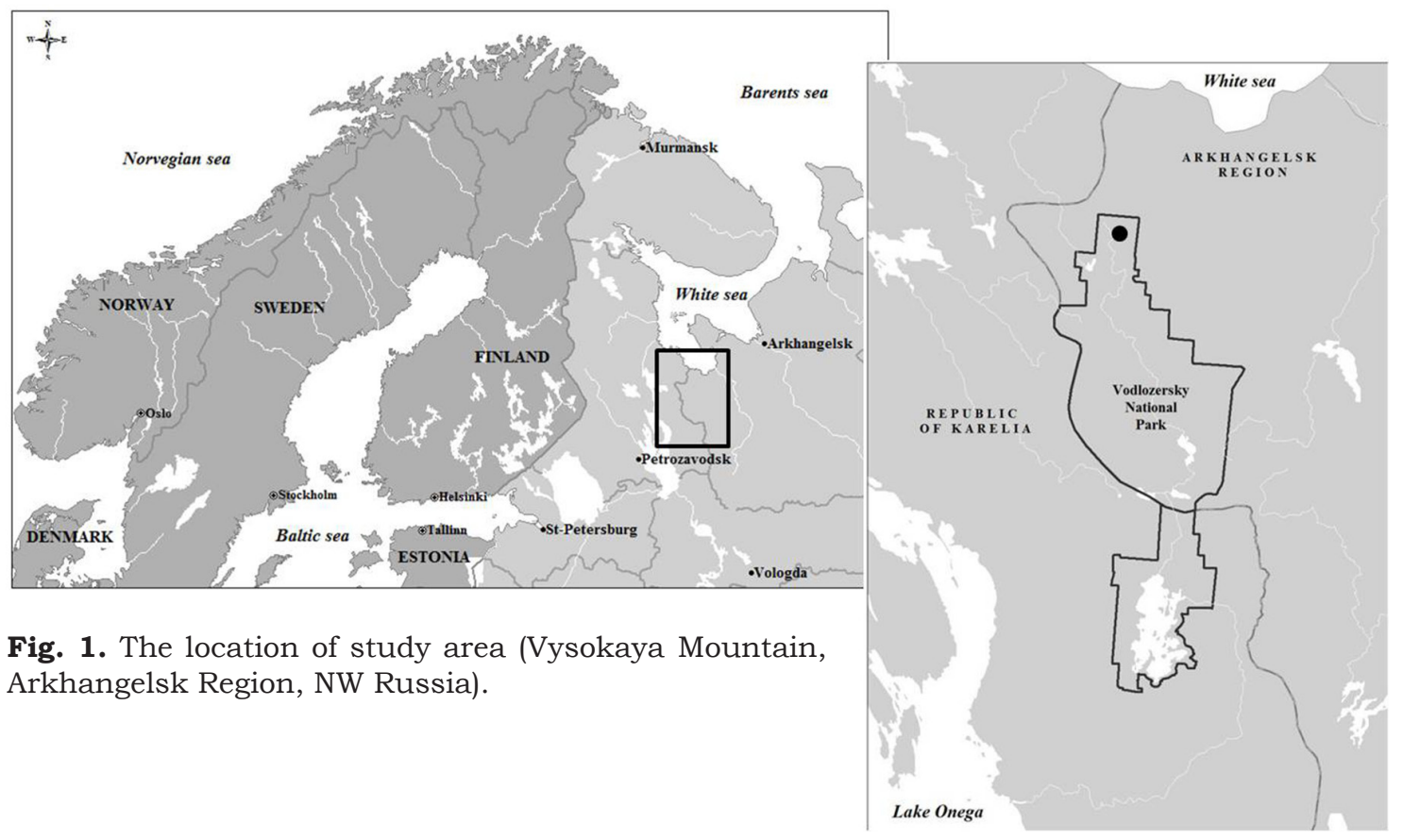


cover) (Methods..., 2002). Studied communities (Fig. 2) are characterized in Table 1.

The epiphytic, saxicolous $(10 \times 20 \mathrm{~cm}$ plots $)$ and ground lichen communities $(1 \times 1 \mathrm{~m}$ plots) were described in detail. The epiphytic lichen cover was studied at 75 trees of spruce and birch on southern and northern expositions, at trunk base and at $130 \mathrm{~cm}$ above ground (600 descriptions). The epilithic lichen cover was described on rocky substrates on different expositions.
Total number of descriptions was 75 for terricolous lichen cover, 520 for saxicolous lichen cover, and 280 for epiphytic lichen cover. To estimate the total lichen species richness, species occurring on all types of substrates were examined: trunks and branches of trees, shrubs, deadwood, mosses, soil and primitive soil covering the surface of the stones, rotting wood and stumps, dead trees, and boulders. The total area of the investigated sample plots was 0.2 ha. Ad-
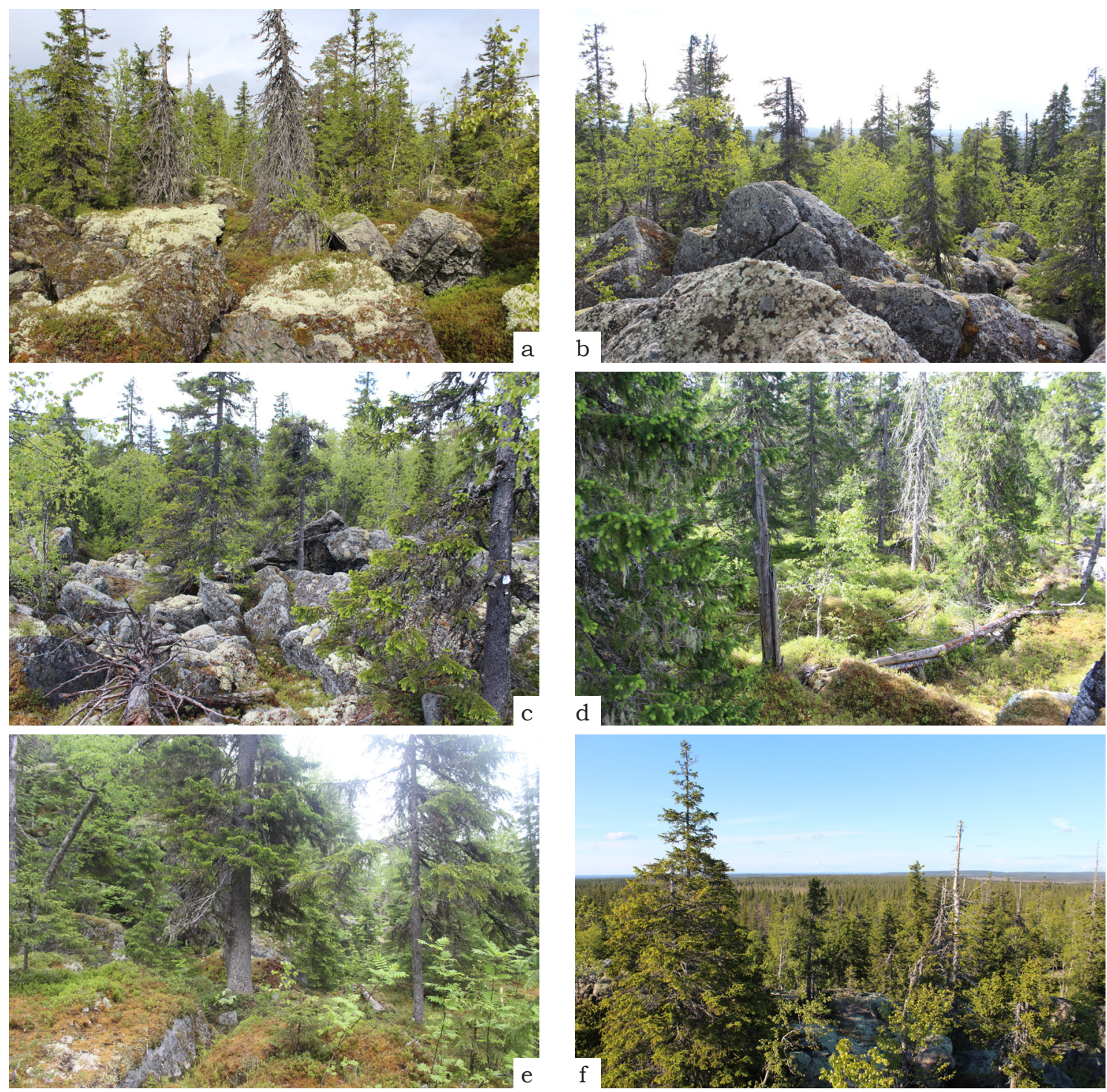

Fig. 2. Studied rocky forest communities: a-e-sample plots $1-5 ; \mathrm{f}-$ view from the northern slope of the mountain Vysokaya to the White Sea. 
Table 1. The main characteristics of studied rocky forest communities of the mountain Vysokaya

\begin{tabular}{|c|c|c|c|c|c|c|c|c|c|c|}
\hline $\mathrm{Sp}$ & $\begin{array}{l}\text { GPS } \\
\text { coordinate }\end{array}$ & $\begin{array}{l}\text { Alt., } \mathrm{m} \\
\text { a.s.l. }\end{array}$ & $\begin{array}{l}\text { Mosses } \\
\text { cover, } \\
\%\end{array}$ & $\begin{array}{l}\text { Herbs- } \\
\text { shrub } \\
\text { cover, } \\
\% \\
\end{array}$ & $\begin{array}{l}\text { Basal area } \\
\text { of living } \\
\text { trees, } \\
\mathrm{m}^{2} \mathrm{ha}^{-1}\end{array}$ & $\begin{array}{l}\text { Basal area } \\
\text { of standing } \\
\text { dead trees, } \\
\mathrm{m}^{2} \mathrm{ha}^{-1}\end{array}$ & $\begin{array}{l}\text { Crown } \\
\text { density, } \\
\%\end{array}$ & $\begin{array}{l}\text { Proportion } \\
\text { of species in } \\
\text { tree stand, \% }\end{array}$ & $\begin{array}{l}\text { Height } \\
\text { of spruce } \\
\text { trees, } \mathrm{m}\end{array}$ & $\begin{array}{l}\text { Age of } \\
\text { spruce } \\
\text { trees, yrs }\end{array}$ \\
\hline 1 & $\begin{array}{l}63^{\circ} 30^{\prime} 51.9 \mathrm{~N} \\
36^{\circ} 37^{\prime} 29.7^{\prime \prime} \mathrm{E}\end{array}$ & 308 & 76 & 28 & 9.3 & 1.8 & 24 & $70 \mathrm{~S} / 30 \mathrm{~B}$ & $8-6$ & $100-280$ \\
\hline 2 & $\begin{array}{l}63^{\circ} 30^{\prime} 50.2^{\prime \prime} \mathrm{N} \\
36^{\circ} 37^{\prime} 27.6^{\prime \prime} \mathrm{E}\end{array}$ & 302 & 82 & 33 & 8.2 & 0.2 & 11 & $60 \mathrm{~S} / 30 \mathrm{~B} / 10 \mathrm{P}$ & $8-7$ & $140-260$ \\
\hline 3 & $\begin{array}{l}63^{\circ} 30^{\prime} 46.9^{\prime \prime} \mathrm{N} \\
36^{\circ} 37^{\prime} 29.2 » \mathrm{E}\end{array}$ & 296 & 81 & 23 & 15.6 & 1.1 & 45 & $90 \mathrm{~S} / 10 \mathrm{~B}$ & $9-13$ & $90-230$ \\
\hline 4 & $\begin{array}{l}63^{\circ} 30^{\prime} 46.4^{\prime \prime} \mathrm{N} \\
36^{\circ} 37^{\prime} 23.6^{\prime \prime} \mathrm{E}\end{array}$ & 287 & 85 & 28 & 15.7 & 1.5 & 48 & $85 \mathrm{~S} / 10 \mathrm{~B} / 5 \mathrm{P}$ & $6-14$ & $170-220$ \\
\hline 5 & $\begin{array}{l}63^{\circ} 30^{\prime} 44.2^{\prime \prime} \mathrm{N} \\
36^{\circ} 37^{\prime} 24.0^{\prime \prime} \mathrm{E}\end{array}$ & 270 & 67 & 25 & 9.9 & 1.1 & 59 & $80 S / 20 B$ & $15-16$ & $45-180$ \\
\hline
\end{tabular}

Notes: $\mathrm{Sp}$ - sample plot, $\mathrm{S}$ - spruce, $\mathrm{B}$ - birch, $\mathrm{P}$ - pine.

ditionally, the lichen diversity was studied on a linear route covering a plateau, all slopes and the foot of mountain Vysokaya. The length of the route was about $2 \mathrm{~km}$ and the duration of its inspectation was ca. 10 hours.

The collected material, a total of about 3000 lichen specimens, was identified using a standard microscopic technique and spot tests. The specimens of the genus Cladonia and sterile crustose lichen species were identified by a standard technique of thin-layer chromatography (TLC) in the Laboratory of Experimental Botany of Petrozavodsk State University (Petrozavodsk) using solvent systems A, B and C (Orange et al., 2001). The specimens of Peltigera genus were confirmed by Orvo Vitikainen, some specimens of genera Cladonia and Stereocaulon were confirmed by Teuvo Ahti (Botanical Museum, University of Helsinki). The cited specimens are deposited in the Herbarium of Petrozavodsk State University (PZV).

\section{LIST OF SPECIES}

Taxa are arranged in alphabetical order; nomenclature of lichens, lichenicolous and nonlichenized fungi follows Nordin et al. (2011). For each species the localities, habitat types and substrates are listed. Lichen substances are given for TLC-analyzed species.

Abbreviations and symbols: \# - lichenicolous fungi; + - non-lichenized fungi; ! - new species for the mainland area of Arkhangelsk Region;
* - new species for Natonal Park "Vodlozersky" (within Arkhangelsk Region); RA - the species that are included in the Red Data Book of Arkhangelsk Region (2020). Localities for species are marked by the number of sample plots (1-5) according to Table 1, while number 6 indicates the species found outside of sample plots along the linear route.

Acolium InQuinans (Sm.) A. Massal. - on snags of spruce; 1, 5-6.

!* AinOA MOOREANA (Carroll) Lumbsch \& I. Schmitt - on stone; 3. In Northern Europe known from Norway (Nordin et al., 2011) and Sweden (Hermansson, 2005). In Russia previously reported only from Murmansk region (NW Russia) (Melekhin, 2009).

Alectoria sarmentosa (Ach.) Ach. - on trunks and branches of spruce, birch and juniper, on snags of coniferous trees; 1-6.

ARCTOPARMELIA CENTRIfuga (L.) Hale - on boulders; 6.

ARTHONIA DISPUNCTA Nyl. - on smooth bark of young willow trees; 3,5 .

ARTHONIA MEDIELLA Nyl. - on wood of spruce; 1.

ARTHONIA PATELLULATA Nyl. - on smooth bark of young aspen trees; 3, 5-6.

ARTHOPYRENIA GRISEA (Schleich. ex Schaer.) Körb. - on bark of birch and deadwood; 1, 4.

+ ARTHOTHELIUM SCANDinAVicUm Th. Fr. - on bark of stand dead trees of spruce; 1,6 .

* Aspicilia laevata (Ach.) Arnold - on boulders and rocks; 4.

Athallia PYRACEA (Ach.) Arup et al. - on bark of rowan; 6. 
BACIDIA IGNIARII (Nyl.) Oxner - on bark of aspen; 5.

BAEOMYCES RUfus (Huds.) Rebent. - on stones, on stones with thin soil layer; 2.

* Bellemerea cinereorufescens (Ach.) Clauzade \& Cl. Roux - on boulders; 2.

Biatora Albohyalina (Nyl.) Bagl. \& Carestia - on smooth bark of young rowan, aspen and willow; 2,6 .

BiATORA BECKHAUsi (Körb.) Tuck. - on bark of willow, birch and rowan; 2, 4, 6.

BiATORA EFFLORESCENS (Hedl.) Erichsen - on bark of deciduous trees; 1, 3-6.

Biatora HELVOLA Korb ex Hellb. - on smooth bark of deciduous trees; 2-6.

BiATORA OCELliformis (Nyl.) Arnold - on bark of aspen and spruce; 6 .

Biatora Pallens (Kullh.) Printzen - on bark of rowan and juniper; 5-6.

!* Biatoridium Delitescens (Arnold) Hafellner on bark of aspen; 6. In Northern Europe known from Sweden and Norway (Nordin et al., 2011). Distribution in neighboring territories: Murmansk region (Urbanavichus et al., 2008), Republic of Karelia (Fadeeva et al., 2007) and Republic of Komi (Hermansson et al., 1998).

Bilimbia Microcarpa (Th. Fr.) Th. Fr. - on bark of aspen; 6.

BRYORIA BICOLOR (Ehrh.) Brodo \& D. Hawksw. - on primary soil; 2, 5. RA.

BRYORIA FURCEllata (Fr.) Brodo \& D. Hawksw. - on branches and trunks of different tree species; 1-6.

BRyoRIA FUSCESCENS (Gyeln.) Brodo \& D. Hawksw. - on branches and trunks of different tree species; 1-6.

* Bryoria glabra (Motyka) Brodo \& D. Hawksw. - on bark of willow; 6 .

BRYORIA NADVORNIKIANA (Gyeln.) Brodo \& D. Hawksw. - on bark and branches of spruce, birch, willow; 1-6.

BuELLIA DISCIFORMIS (Fr.) Mudd - on bark of willow and rowan; 1, 5-6.

BUELLIA ERUBESCENS Arnold - on bark of willow; 6 .

BuEllia GRISEOVIRENS (Turner \& Borrer ex. Sm.) Almb. - on bark of willow and rowan, on standing deadwood of spruce; 1, 3, 5 .

Calicium denigratum (Vain.) Tibell - on standing deadwood of spruce and bark of willow; 6 .

Calicium Glaucellum Ach. - on bark and standing deadwood of spruce and pine, on bark of birch and aspen; 1-6.
CALICIUM PARVUm Tibell - on bark of spruce and birch, on standing deadwood of spruce, pine and willow; 1-4, 6 .

Calicium trabinellum (Ach.) Ach. - on wood of spruce, pine, birch and willow; 1-4, 6 .

CAlicium viride Pers. - on wood and bark of spruce; 1-4, 6.

Caloplaca borealis (Vain.) Poelt - on smooth bark of young rowan; 2.

CATiNARIA ATROPURPUREa (Schaer.) Vězda \& Poelt - on bark of aspen and birch, on standing deadwood of spruce; 1-3, 5-6.

CATINARIA NEUSChILDII (Körb.) P. James - on bark of aspen; 6.

Cetraria islandica (L.) Ach. - on soil; 1-6.

Cetraria odontella (Ach.) Ach. - on soil, on rocks and boulders, on deadwood of spruce; $1-2,6$.

Cetraria sepincola (Ehrh.) Ach. - on bark of trunk and branches of birch, willow and rowan; 1-6.

ChaEnotheca BRAchypoda (Ach.) Tibell - on bark of aspen and deadwood of spruce; 3, 6. RA.

Chaenotheca BRunneola (Ach.) Müll. Arg. - on bark and deadwood of spruce and pine; $3-4,6$.

ChaEnotheca CHRYsocephala (Turner ex Ach.) Th. Fr. - on bark and deadwood of spruce, pine and birch; 3, 5-6.

Chaenotheca ferruginea (Turner $\&$ Borrer) Mig. - on bark and deadwood of spruce, pine and birch; 3-4, 6.

Chaenotheca Phaeocephala (Turner) Th. Fr. - on bark of spruce; 6. RA.

Chaenotheca Sphaerocephala Nádv. - on bark of spruce; 6. RA.

Chaenotheca stemonea (Ach.) Müll. Arg. - on bark of spruce; 5 .

Chaenotheca subroscida (Eitner.) Zahlbr. - on bark of spruce; $1-4,6$.

Chaenotheca trichialis (Ach.) Th. Fr. - on bark and deadwood of spruce and birch; 1-6.

\# Chaenothecopsis consociata (Nádv.) A. F. W. Schmidt - on thalli of Chaenotheca chrysocephala on bark of spruce; 3,5 .

! * \# Chaenothecopsis Debilis (Sm.) Tibell - on bark of dead birch tree; 3. In Northern Europe known from Finland, Sweden and Norway (Nordin et al., 2011). Distribution in neighboring territories: Leningrad region (Kuznetsova et al., 2007), Murmansk region (Urbanavichus \& Urbanavichene, 2017), Re- 
public of Karelia (Fadeeva et al., 2007) and Republic of Komi (Hermansson et al., 1998).

\# ChaEnothecopsis epithallina Tibell - on thalli of Chaenotheca trichialis, on bark and wood of spruce; 1, 3-6.

\# Chaenothecopsis fennica (Laurila) Tibell - on bark of spruce; 3,6 .

\# Chaenothecopsis nana Tibell - on bark of spruce; 3, 6.

\# Chaenothecopsis nigra Tibell - on bark of spruce; 3.

\# Chaenothecopsis pusilla (Ach.) A. F. W. Schmidt - on bark and deadwood of spruce, birch, aspen, willow; 1-6.

\# ChAENothecopsis PUSIOLA (Ach.) Vain. - on bark of spruce; 3, 6 .

\# CHAENothecopsis SAVONICA (Räsänen) - on bark and deadwood of spruce; 2-3, 5-6.

\# Chaenothecopsis viridialba (Kremp.) A. F. W. Schmidt - on bark of spruce; 2.

\# ChaENothecopsis ViRidireagens (Nádv.) A. F. W. Schmid - on bark of spruce; 6 .

Cladonia albonigra Brodo \& Ahti - on stones and boulders with thin soil layer; 1,3 .

Cladonia amaurocraea (Flörke.) Schaer. - on stones and boulders with thin soil layer; 1-6.

Cladonia arbuscula (Wallr.) Flot. - on soil; 4-6.

Cladonia BACILLIFORMIS (Nyl.) Glück - on decaying wood of fallen spruce trees, at trunk base of birch; 1-6.

Cladonia Bellidiflora (Ach.) Schaer. - on soil, on stones and boulders with thin soil layer; $1-2,6$.

Cladonia borealis S. Stenroos - on soil, on stones and boulders with thin soil layer; 1-3, 6 .

Cladonia botrytes (K. G. Hagen) Willd. - on decaying wood of spruce; $1-3,6$.

Cladonia Carneola (Fr.) Fr. - on decaying wood of spruce and birch; 1, 5-6.

Cladonia cenotea (Ach.) Schaer. - on soil, on decaying wood, at trunk base of different tree species; $1-6$.

Cladonia chlorophaea (Flörke ex Sommerf.) Spreng. - on soil, at trunk base, on fallen trees; 1-6. The specimens contain fumarprotocetraric acid.

Cladonia Coccifera (L.) Willd. - on soil, on stones and boulders with thin soil layer; 1-6.

Cladonia coniocraea (Flörke) Spreng. - on soil, on decaying wood, at trunk base of different tree species; 1-6.
Cladonia cornuta (L.) Hoffm. - on soil, on stones and boulders with thin soil layer, at trunk base; $1-6$.

Cladonia cornuta subsp. GRoenlandica (Å.E. Dahl) Ahti - on stones and boulders with thin soil layer, at trunk base and decaying wood of spruce; 1, 5-6.

Cladonia CRISPATA (Ach.) Flot. - on soil, on stones and boulders with thin soil layer, at trunk base and decaying wood of spruce; 1-6.

* Cladonia CRYPTOChlorophaEa Asahina - at trunk base of spruce; 1 . The specimens contain cryptochlorophaeic, paludosic acids and fumarprotocetraric acid complex.

Cladonia Cyanipes (Sommerf.) Nyl. - on soil, on stones and boulders with thin soil layer, at trunk base of spruce; 4-6.

Cladonia DEFormis (L.) Hoffm. - on soil, on mossy boulders, on decaying wood, at trunk base of different tree species; $1-6$.

Cladonia digitata (L.) Hoffm. - on soil, on decaying wood, at trunk base of different tree species; 1-6.

Cladonia fimbriata (L.) Fr. - on decaying wood, at trunk base of different tree species; 1-6.

Cladonia GRACILIS subsp. ElONGATA (Wulfen) Vain. - on soil, on stones and boulders with thin soil layer, on decaying wood; 1-6.

Cladonia gracilis subsp. TURBinata (Ach.) Ahti - on soil, on stones and boulders with thin soil layer, on decaying wood; 1-6.

Cladonia GRAYI G. Merr. ex Sandst. - on soil, on stones and boulders with thin soil layer, on decaying wood; $1-6$. The specimens contain grayanic acid.

Cladonia macrophylla (Schaer.) Stenh. - on stones and boulders with thin soil layer, on mossy boulders, at trunk base of birch; 1-6.

Cladonia MEROCHLOROPHAEA Asahina - at trunk base of spruce; 4. The specimens contain merochlorophaeic and 4-O-methylcryptochlorophaeic acids, fumarprotocetraric acid complex.

Cladonia mitis Sandst. - on soil, on stones and boulders with thin soil layer; 1-4, 6 .

* Cladonia norvegica Tønsberg \& Holien - on decaying wood, at trunk base of birch; 2-4.

Cladonia OCHROCHLORA Flörke - on stones and boulders with thin soil layer; 3 .

Cladonia Parasitica (Hoffm.) Hoffm. - on decaying wood, at trunk base of spruce; 1-2, 5 . 
Cladonia PHYllophora Hoffm. - on stones and boulders with thin soil layer, on decaying wood; 3-4, 6.

Cladonia Pleurota (Flörke) Schaer. - on soil, on stones and boulders with thin soil layer, at trunk base, decaying wood; 1-6.

Cladonia PyXidata (L.) Hoffm. - on soil, on stones and boulders with thin soil layer, on trunk of spruce and aspen; 3-4, 6 .

Cladonia Rangiferina (L.) Weber ex F. H. Wigg. - on soil, on stones and boulders with thin soil layer, at trunk base, decaying wood; 2-6.

Cladonia squamosa Hoffm. - on soil, on stones and boulders with thin soil layer, at trunk base, decaying wood; 1-6.

Cladonia stellaris (Opiz) Pouzar \& Vezda - on soil, on stones and boulders with thin soil layer, at trunk base; 1-6.

Cladonia stygia (Fr.) Ruoss - on soil; 1 .

Cladonia subfurcata (Nyl.) Arnold - on soil, on stones and boulders with thin soil layer; $1-2$.

Cladonia subulata (L.) Weber ex F. H. Wigg. - on soil, on stones and boulders with thin soil layer; 3-4.

Cladonia sulphurina (Michx.) Fr. - on soil, on stones and boulders with thin soil layer, at trunk base, decaying wood; 1-6.

Cladonia uncialis (L.) Weber ex F. H. Wigg - on soil, on stones and boulders with thin soil layer; $1-6$.

* Cliostomum leprosum (Räsänen) Holien \& Tønsberg - on branches of spruce; 6 .

Coenogonium Pineti (Ach.) Lücking \& Lumbsch - on smooth bark of rowan; 5.

Cystocoleus ebeneus (Dillwyn) Thwaites - on boulders and rocks; 3.

!* Diploschistes muscorum (Scop.) R. Sant. - on mossy boulders and rocks; 3. In Northern Europe known from Finland, Sweden and Norway (Nordin et al., 2011). Distribution in neighboring territories: Leningrad region (Himelbrant et al., 2015), Murmansk region (Urbanavichus et al., 2008), Republic of Karelia (Fadeeva et al., 2007) and Republic of Komi (Hermansson et al., 1998).

DiplOSCHISTES SCRUPOSUS (Schreb.) Norman - on boulders and rocks; 2-3.

EVERNIA MESOMORPHA Nyl. - on branches and decaying wood of spruce; $1,4,6$.

FlavocetraRia nivalis (L.) Kärnefelt \& A. Thell on soil; $1-6$.

FRUTIDELLA CAESIOATRA (Schaer.) Kalb - on stones and boulders with thin soil layer; 1-2.
Frutidella furfuracea (Anzi) M. Westb. \& M. Svensson - on bark of birch and juniper; $1-6$.

Fuscidea PUSILla Tønsberg - on bark of rovan and juniper; $1,5-6$. The specimens contain divaricatic acid.

Gyalecta truncigena (Ach.) Hepp - on smooth bark of young aspen; 3 .

Gyalolechia flavoRUBESCEns (Huds.) Søchting et al. - on bark of aspen; 6 .

!* HaEmatomma ochroleucum (Neck.) J. R. Laundon - on stones and boulders; 2-3. In Northern Europe known from Finland, Sweden and Norway (Nordin et al., 2011). Distribution in neighboring territories: Leningrad region (Kuznetsova et al., 2007), Murmansk region (Konoreva et al., 2017), Republic of Karelia (Fadeeva et al., 2007) and Republic of Komi (Hermansson et al., 1998).

Hypocenomyce scalaris (Ach.) M. Choisy - on bark of spruce; 1-6.

HyPOGYMNIA BITTERI (Lynge) Ahti - on bark and wood of spruce, birch; 1-2, 4, 6 .

HyPogymnia PHYSOdES (L.) Nyl. - on trunks, branches, decaying wood of different tree species; $1-6$.

HYPOGYMNIA TUBUlosa (Schaer.) Hav. - on trunks, branches, decaying wood of different tree species; 1-6.

Hypogymnia vitTata (Ach.) Parrique - on bark of sprice, pine and birch; 1-2, 5-6.

ICMADOPHILA ERICETORUM (L.) Zahlbr. - on soil; 3.

IMSHAUGIA ALEURITES (Ach.) S. L. F. Mey. - on wood and bark of birch; 2,6 .

JAPEWIA SUBAURIFERA Muhr \& Tønsberg - on bark and wood of different trees; 1-6.

JAPEWIA TORNOËNSIS (Nyl.) Tønsberg - on bark of spruce and birch, on smooth bark of willow and rowan; 1-6.

LECANIA CYRTELla (Ach.) Th. Fr. - on smooth bark of rowan; 2,6 .

LeCANia CyRTELlina (Nyl.) Sandst. - at base of pine trunk; 6.

LeCANiA NAEGEli (Hepp) Diederich \& van den Boom - on smooth bark of rowan and wood of pine; $5-6$.

LeCANORA AlBellula (Nyl.) Th. Fr. var. albellula (Nyl.) Th. Fr. - on bark of birch, juniper, on wood of spruce; 4, 6 .

LECANORA ALLOPHANA Nyl. - on smooth bark of rowan; 3.

LeCANORA CATEILEA (Ach.) A. Massal. - on smooth bark of rowan; 3. 
LECANORA CHLAROTERA Nyl. - on bark of deciduous trees; $1-6$.

LECANORA CIRCUMBOREALIS Brodo et Vitik. - on bark of rowan and pine; 5-6.

* Lecanora fuscescens (Sommerf.) Nyl. - on smooth bark of rowan; 6 .

LECANORA HYPOPTA (Ach.) Vain. - on wood of pine; 6.

!* LeCANORA hypoptoides (Nyl.) Nyl. - on bark of spruce; 4. In Northern Europe known from Finland, Sweden and Norway (Nordin et al., 2011). Distribution in neighboring territories: Leningrad region (Kuznetsova et al., 2007) and Murmansk region (Urbanavichus et al., 2008). LECANORA INTRICATA (Ach.) Ach. - on boulders, 2 .

LECANORA PHAEOSTIGMA (Körb.) Almb. - on bark and wood of different tree species; 1-6.

LECANORA POPULICOLA (DC.) Duby - on bark of rowan; 6.

LECANORA PULICARIS (Pers.) Ach. - on bark and wood of different tree species; 1-6.

LeCANora symmicta (Ach.) Ach. - on bark of spruce and aspen; 6 .

LECIDEA ALBOFUSCESCENS Nyl. - on smooth bark of deciduous trees; 3,6 .

LECIDEA ERYTHROPHAEA Flörke ex Sommerf. - on bark of aspen; 6 .

LECIDEA LEPRARIOIDES Tønsberg - on bark of spruce; 1 .

LECIDEA NYLANDERI (Anzi) Th. Fr. - on bark and wood of spruce, pine and birch; 1-6.

LECIDEA TURGIDULA Fr. - on wood of spruce and willow; 5-6.

LEPRA ALBESCENs (Huds.) Hafellner - on bark of spruce and aspen; 1, 4, 6 .

LEPRA AMARA (Ach.) Lohtander \& Tønsberg - on boulders; $1,3$.

LEPRARIA BOREALIS Lohtander \& Tønsberg - on boulders; 1,3 . The specimens contain atranorin, roccellic/angardianic, jackinic/ rangiformic acid.

!* LePRARIA CAEsioalba (B. de Lesd.) J. R. Laundon - on soil and boulders; 4-6. The specimens contain atranorin, fumarprotocetraric, protocetraric and roccellic/angardianic acids. In Northern Europe known from Finland, Sweden and Norway (Nordin et al., 2011). Distribution in neighboring territories: Leningrad region (Stepanchikova et al., 2014), Murmansk region (Urbanavichus et al., 2008) and Republic of Karelia (Fadeeva et al., 2007).
* LePRARIa elobata Tønsberg - on bark of spruce; 4. The specimen contains atranorin, zeorin and stictic acid complex.

LEPRARIA JACKII Tønsberg - on bark of spruce; 1-6. The specimens contain atranorin, roccellic/angardianic, jackinic/rangiformic and norjackinic/norrangiformic acid.

LEPRARIA INCANA (L.) Ach. - on bark of spruce; 5. The specimens contain divaricatic acid, atranorin and zeorin.

LEPRARIA NEGLECTA (Nyl.) Lettau - on soil, on stones and boulders with thin soil layer; $1-4$. The specimens contain alectorialic acid.

+ LEPTORHAPHIS EPIDERMIDIS (Ach.) J. Kickx f. - on bark of birch; 1-6.

LOBARIA PULMONARIA (L.) Hoffm. - on bark of aspen, willow and birch; 5-6. RA.

LOBARIA SCROBICULATA (Scop.) DC. - on bark of birch; 6. RA.

* LOPADIUM Disciforme (Flot.) Kullh. - on bark of birch and spruce; 6 .

LOXOSPORA ElATiNa (Ach.) A. Massal. - on bark and wood of spruce and birch; 1-6.

!* Melanelia agnata (Nyl.) A. Thell - on boulders and rocks; 2. In Northern Europe known from Sweden and Norway (Nordin et al., 2011). Distribution in neighboring territories: Murmansk region (Urbanavichus et al., 2008) and Republic of Komi (Lavrinenko et al., 2005).

Melanelia stygia (L.) Essl. - on boulders and rocks; 3.

Melanohalea olivacea (L.) O. Blanco et al. - on bark of deciduous and coniferous trees; 1-6.

Melanohalea sePTEnTRIonalis (Lynge) O. Blanco et al. - on bark of deciduous trees; 1-6.

Micarea denigrata (Fr.) Hedl. - on bark of birch and willow; 4, 6.

MicAREA Globulosella (Nyl.) Coppins - on bark of spruce, birch, aspen, on standing deadwood; 3,6 . The specimens contain gyrophoric acid.

Micarea MELAENa (Nyl.) Hedl. - on bark and wood of pine; 2,6 .

MicAREA MiselLa (Nyl.) Hedl. - on wood of spruce; $1,3,6$. The specimen does not contain any substances.

MicAREA PEliocarpa (Anzi) Coppins \& R. Sant. on falling tree of spruce; 4. The specimens contain gyrophoric acid.

* Microcalicium ahlneri Tibell - on bark of pine dead tree; 6.

* Microcalicium arenarium (Hampe ex A. Massal.) Tibell - on wood of spruce; 6 . 
Microcalicium disseminatum (Ach.) Vain. - on bark and wood of spruce, pine; 1-6.

MonTANElia SOREDiATA (Ach.) Divakar et al. - on boulders and rocks; 5 .

Mycobilimbia CARneOAlBida (Müll. Arg.) S. Ekman \& Printzen - on bark of deciduous trees; 4, 6 .

MYCOBILIMBIA EPIXANTHOIDEs (Nyl.) Vitik. et al. - on bark of aspen; 6.

MyCOBILIMBIA TETRAMERA (De Not.) Vitik. et al. - on bark of aspen; 6 .

Mycoblastus AFFinis (Schaer.) T. Schauer - on bark and wood of different tree species; 1-6.

* Mycoblastus alpinus (Fr.) Th. Fr. ex Hellb. - on bark of spruce and rarely on smooth bark of willow; 3, 5-6. The specimens contain atranorin, chloroatranorin, planaic and usnic acids.

Mycoblastus SANGUiNARIUS (L.) Norm. - on bark and wood of different tree species; 1-6.

+ Mycocalicium subtile (Pers.) Szatala - on bark and wood of spruce, pine and aspen; 4-6.

NAETROCYMBE PUNCTIFORMIS (Pers.) R.C. Harris - on smooth bark of rowan, willow, aspen; 5-6.

NePhroma ARCTICUM (L.) Torss. - on soil; 2-3.

NePHROMA BELlum (Spreng.) Tuck. - on bark of aspen; 6.

NEPHROMA PARILE (Ach.) Ach. - on bark of aspen and willow; 5-6.

OCHROLECHIA ALBOflaVescens (Wulfen) Zahlbr. on wood of spruce; 1 . The specimens contain variolaric, lichesterinic and protolichesterinic acids.

OCHROLECHIA FRIGIDA (Sw.) Lynge - on soil, on stones with thin soil layer, on bark of spruce; $1-6$. The specimens contain gyrophoric and lecanoric acids.

OCHROLECHIA MAHLUENSIS Räsänen - on bark of spruce; $1-6$. The specimens contain gyrophoric and lecanoric acids.

OCHROLECHIA MICROSTICTOIDES Räsänen - on bark and wood of different tree species; $1-6$. The specimens contain variolaric and lichesterinic acids.

OCHROLECHIA PALLESCENS (L.) A. Massal. - on bark of spruce and birch; 1-2, 6 .

Palicella filamentosa (Stirt.) Rodr. Flakus et Printzen - on bark of birch; 1.

!* ORPhNiospora Mosigil (Körb.) Hertel \& Rambold - on boulders and rocks; 1 . In Northern Europe known only from Northern Norway (GBIF Backbone Taxonomy). In European Russia known only from Murmansk region (Urbanavichus et al., 2008).
Parmelia saxatilis (L.) Ach. - on stones with thin soil layer; 1-6.

PARMELIA SULCATA Taylor - on bark and wood of different tree species; $1-6$.

PARMELIOPSIS AMBIGUA (Wulfen) Nyl. - on bark and wood of different tree species; 1-6.

PARMELIOPSIS HYPEROPTA (Ach.) Arnold - on bark and wood of different tree species; 1-6.

Peltigera aphthosa (L.) Willd. - on soil; 3-6.

Peltigera Canina (L.) Willd. - at trunk base of aspen; 6 .

Peltigera leucophlebia (Nyl.) Gyeln. - on soil; 3,5 .

Peltigera malacea (Ach.) Funck - on soil and mosses; 5-6.

Peltigera membranacea (Ach.) Nyl. - on soil; 6.

Peltigera NEOPOlydactyla (Gyeln.) Gyeln. - on soil and mosses; 3, 6 .

Peltigera occidentalis (E. Dahl) Kristinsson - on soil and mossy stone; 3,6 .

Peltigera PRAetextata (Flörke ex Sommrerf.) Zopf - at trunk base of aspen; 6 .

Pertusaria Carneopallida (Nyl.) Anzi ex Nyl. - on bark of rowan and aspen; 2-6.

Pertusaria geminipara (Th. Fr.) C. Knight ex Brodo - on soil; $1-2,4$.

PERTUSARIA LEIOPLACA DC. - on smooth bark of rowan; 6.

Pertusaria OPHTHALmiza (Nyl.) Nyl. - on bark of birch and spruce, 4, 6 .

Phlyctis ARgena (Spreng.) Flot. - on bark of aspen; 5-6.

Physcia AlNophila (Vain.) Loht. et al. - on bark of rowan; 1.

* Physcia Caesia (Hoffm.) Fürnr. - on boulders; $3,6$.

Placynthiella icmalea (Ach.) Coppins \& P. James - on rotting wood, on standing deadwood of spruce; 6.

Placynthiella oligotropha (J. R. Laundon) Coppins \& P. James - on wood of spruce and soil; 6.

* Placynthiella uliginosa (Schrad.) Coppins \& P. James - on stone; $1,3$.

Platismatia glauca (L.) W. L. Culb. \& C. F. Culb. - on bark and wood of different tree species; 1-6.

PoRPIDIA CINEREOATRA (Ach.) Hertel \& Knoph - on boulders and rocks; 3 .

Porpidia CRUSTUlata (Ach.) Hertel \& Knoph - on boulders and rocks; 2-5.

PoRPIDIA FLAVICUNDA (Ach.) Gowan - on boulders and rocks; 1-6. 
!* Porpidia GRisea Gowan - on boulders and rocks; 2-3. In Northern Europe known from Finland, Sweden and Norway (Nordin et al., 2011). Distribution in neighboring territories: Leningrad region (Gowan \& Ahti, 1993), Murmansk region (Urbanavichus et al., 2008) and Republic of Karelia (Fadeeva et al., 2007).

PorPIDIA MACROCARPA (DC) Hertel \& A. J. Schwab - on stones and boulders; $1-3$.

Porpidia tuberculosa (Sm.) Hertel. \& Knoph - on boulders and rocks; $2-3$.

!* Protothelenella corrosa (Körb.) H. Mayrhofer \& Poelt - on boulders and rocks; 4. In Northern Europe known from Finland, Sweden and Norway (Nordin et al., 2011). Distribution in neighboring territories: Leningrad region (Stepanchikova et al., 2014), Murmansk region (Urbanavichus et al., 2008) and Republic of Karelia (Fadeeva et al., 2007).

PSEUdEVERNIA FURFURACEA (L.) Zopf. - on bark and wood of spruce and pine; 1-2, 6. RA.

Psilolechia LUCida (Ach.) M. Choisy - on boulders, on rotting wood; 3, 6 .

* Pycnora sorophora (Vain.) Hafellner - on bark of willow and spruce; 6 .

PyCNORA XANTHOCOCCA (Sommerf.) Hafellner - on bark of aspen; 3.

RACODIUM RUPESTRE Pers.: Fr. - on mossy boulders and rocks; 3.

RAMALINA FARINACEA (L.) Ach. - on bark of aspen; 6.

RAmBOLDIA CINNABARINA (Sommerf.) Kalb et al. on bark of standing deadwood of spruce, 1, 3, 6. RA.

RAmboldia Elabens (Fr.) Kantvilas \& Elix - on worked timber; 6 .

RHIZOCARPON BADIOATRUM (Flörke ex Spreng) Th. Fr. - on boulders and rocks; 1-2.

RHIZOCARPON EUPETRAEUM (Nyl.) Arnold - on boulders and rocks; 2.

!* Rhizocarpon FRIGIDUM Räsänen- on boulders and rocks; 2. In Northern Europe known from Finland, Sweden and Norway (Nordin et al., 2011). Distribution in neighboring territories: Murmansk region (Urbanavichus et al., 2008) and Republic of Karelia (Fadeeva et al., 2007).

RHIZOCARPON GEOGRAPHICUM (L.) DC. - on boulders and rocks; 1-6.

!* Rhizocarpon polycarpum (Hepp) Th. Fr. - on boulders and rocks; 2. In Northern Europe known from Finland, Sweden and Nor- way (Nordin et al., 2011). Distribution in neighboring territories: Leningrad region (Kuznetsova et al., 2007), Murmansk region (Urbanavichus et al., 2008) and Republic of Karelia (Fadeeva et al., 2007).

!* Rinodina cinereovirens (Vain.) Vain. - on smooth bark of aspen; 6. In Northern Europe known from Finland, Sweden and Norway (Nordin et al., 2011). Distribution in neighboring territories: Murmansk region (Urbanavichus et al., 2008), Republic of Karelia (Fadeeva et al., 2007) and Republic of Komi (Hermansson et al., 1998).

!* Ropalospora lugubris (Sommerf.) Poelt - on boulders and rocks; 1, 3. In Northern Europe known from Finland, Sweden and Norway (Nordin et al., 2011). Distribution in neighboring territories: Leningrad region (Brenner, 1886), Murmansk region (Urbanavichus et al., 2008), Republic of Karelia (Fadeeva et al., 2007) and Republic of Komi (Hermansson et al., 1998).

Rostania occultata (Bagl.) Otálora, P. M. Jørg. $\&$ Wedin - on bark of aspen; 6 .

+ SAREA DiFFORMis (Fr.) Fr. - on resin of spruce; 6.

+ SAREA Resinae (Fr.) Kuntze - on resin of spruce; 6.

Scoliciosporum CHLOROCOCCUM (Graewe ex Stenh.) Vězda - on smooth bark of willow and on bark of birch; 2, 5-6.

Scutula CIRCUMSPECTA (Vain.) Kistenich et al. - on bark of willow; 5 .

SCytinium teRETiUsculum (Wallr.) Otálora et al. on bark of aspen; 6 .

STEINIA GEOPHANA (Nyl.) Stein - on bark of aspen; 1.

!* Stereocaulon evolutum Graewe - on primary soil over boulders; 1 . In Northern Europe known from Finland, Sweden and Norway (Nordin et al., 2011). Distribution in neighboring territories: Republic of Karelia (Fadeeva et al., 2007).

Stereocaulon Grande (H. Magn.) H. Magn - on primary soil over boulders; 1 .

Stereocaulon Paschale (L.) Hoffm. - on soil, on primary soil over boulders; 1-2, 5 .

Stereocaulon saxatile H. Magn. - on soil, on boulders, on primary soil over boulders; 4-6.

Stereocaulon subCORALloides (Nyl.) Nyl. - on stones and mossy boulders, on primary soil over boulders; 1, 4-6.

Thamnolia Vermicularis (Sw.) Schaer. s. lat. - on soil; on primary soil over boulders; $1-2$. 
Toensbergia leucococca (R. Sant.) Bendiksby \& Timdal - on smooth bark of willow and alder, on spruce branches of spruce; 1,6 .

TONINIOPSIS SUBINCOMPTA (Nyl.) Kistenich et al. - on bark of willow; 6 .

TRAPEliopsis flexuOSA (Fr.) Coppins \& P. James on soil, on wood of spruce, on rotting wood; $1-2,6$.

TRAPELIOPSIS GRANUlOSA (Hoffm.) Lumbsch - on soil, on wood of spruce, on rotting wood; $1,3,5$.

TUCKERMANNOPSIS CHLOROPHYLLA (Willd.) Hale - on trunks and branches of deciduous and coniferous trees; 1-6.

UMBILICARIA DEUSTA (L.) Baumg. - on boulders and rocks; 2 .

!* Umbilicaria hiRsuta (Sw. ex Westr.) Hoffm. - on boulders and rocks; 5. In Northern Europe known from Finland, Sweden and Norway (Nordin et al., 2011). Distribution in neighboring territories: Leningrad region (Alexeeva, 2005), Murmansk region (Urbanavichus et al., 2008), Republic of Karelia (Fadeeva et al., 2007) and Republic of Komi (Hermansson et al., 1998).

UMBILICARIA HYPERBOREA (Ach.) Hoffm. - on boulders and rocks; 2.

* Umbilicaria PRoBoscidea (L.) Schrad. - on boulders and rocks; 4.

UMBILICARIA TORREFACTA (Lightf.) Schrad. - on boulders and rocks; 2.

* Usnea barbata (L.) Weber ex F. H. Wigg. - on bark of aspen and willow; 6 .

USNEA DASYPOGA (Ach.) Nyl. - on bark and wood of different tree species; 1-6.

USNEA LAPPONICA Vain. - on branches of birch; 4.

USNEA SUBFLORIDANA Stirt. - on bark and wood of different tree species; 1-6.

!* Vahliella leucophaea (Vahl) P. M. Jørg. - on bark of aspen; 6. In Northern Europe known from Finland, Sweden and Norway (Nordin et al., 2011). Distribution in neighboring territories: Leningrad region (Kuznetsova et al., 2007), Murmansk region (Urbanavichus et al., 2008), Republic of Karelia (Fadeeva et al., 2007) and Republic of Komi (Hermansson et al., 1998).

VARICELLARIA RHODOCARPA (Körb.) Th. Fr. - on bark of spruce, birch and pine, on standing deadwood; 1, 3, 6. RA.

Violella fucata (Stirt.) T. Sprib. - on bark of rowan and spruce; $1,3,6$. The specimens contain atranorin and fumarprotocetraric acid.
VulPicida PINASTRI (Scop.) J.-E. Mattsson \& M. J. Lai - on bark and wood of different tree species; 1-6.

Xanthoparmelia stenophylla (Ach.) Ahti \& D. Hawksw. - on primary soil over boulders; 1.

XYLOGRAPHA DIFFORMIS Vain. - on bark of spruce; 2.

Xylographa Pallens (Nyl.) Malmgren - on wood of spruce and birch; 1-3, 6.

Xylographa Parallela (Ach.: Fr.) Fr. - on decaying wood of spruce; $1-6$.

XYLOGRAPHA RUBESCENS Räsänen - on decaying wood of spruce and juniper, 2, 4, 6 .

XylogRaPha tRUnCiseda (Th. Fr.) Minks ex Redinger - on decaying wood of spruce; $1,3-4,6$.

XYLOGRAPHA VITILIGO (Ach.) J. R. Laundon - on decaying wood of spruce and birch; 1-2, 4, 6 . The specimens contain stictic acid complex.

XYLOPSORA FRIESII (Ach.) Bendiksen \& Timdal - on bark and wood of spruce; 1-6.

\section{DISCUSSION}

As a result of the study, 270 species and 2 subspecies of lichens and allied fungi belonging to 51 families and 101 genera were found in the rocky forest communities of mountain Vysokaya.

Among the recorded species, 18 lichens are reported for the first time for the mainland area of the Arkhangelsk Region. We also can add 35 new species to the list of lichens and allied fungi of the Vodlozersky National Park (Arkhangelsk part).

The species Lobaria pulmonaria is included in the Red Data Book of Russian Federation (Red..., 2008), and 9 recorded species are listed in the Red Data Book of Arkhangelsk Region (2020): Bryoria bicolor, Chaenotheca brachypoda, C. phaeocephala, C. sphaerocephala, Lobaria pulmonaria, L. scorbiculata, Pseudevernia furfuracea, Ramboldia cinnabarina, and Varicellaria rhodocarpa.

Analysis of lichen substrates from the studied communities revealed the predominance of epiphytic group (corticolous and lignicolous) (164 species, 50\%). Terricolous lichens were the second dominant group (60 species, $22 \%$ ). The saxicolous lichens were represented by the lowest species number (39 species, 14\%) but characterized by a high substrate specificity 
(36 species were found on stones only). Some lichen species (10 species, 4\%) were relatively nonspecific for substrates.

Crustose species were dominant (165 species; $61 \%$ ) among the main growth forms of listed lichens. Fruticose and foliose lichens accounted for $67(25 \%)$ and $40(15 \%)$ species, respectively.

The species diversity of lichens was evaluated by combination of two study methods: sample plots and linear route. Within studied sample plots (0.04 ha), the total number of species varied from 113 (SP 5) to 136 (SP 3). Thus, within the plots, $41-50 \%$ of the total lichen diversity of the rocky outcrops was represented. All the studied communities had quite similar characteristics (geology, vegetation type, time-since-last disturbance, the presence of substrates) (Table 1). However, they differed in their positions on the transect and, consequently, in heights above sea level. Density and height of tree stand increased down the slope (Table 1). The difference in elevation between the first and last sample plot was only $38 \mathrm{~m}$. However, this amplitude was enough to observe the influence of the altitudinal gradient on the species composition of lichens. Thus, according to the obtained results, arctic-alpine species (Urbanavichus, 2010) were only found on the plateau of mountain and in the upper part of the slope: Bryoria bicolor, Cladonia albonigra, C. bellidiflora, C. stygia, C. subfurcata, Frutidella caesioatra, Steinia geophana, Stereocaulon evolutum, Thamnolia vermicularis, Umbilicaria hyperborea.

In fact, typical boreal species with more southern distribution (Urbanavichus, 2010) were only recorded at the foot of the mountain: Athallia pyracea, Bacidia igniarii, Biatora ocelliformis, B. pallens, Biatoridium delitescens, Bilimbia microcarpa, Buellia erubescens, Coeogonium pineti, Gyalolechia flavorubescens, Lecania naegelii, Lecanora populicola, Lecidea erytrophaea, Lopadium disciforme, Mycobilimbia epixanthoides, $M$. tetramera, Nephroma bellum, N. parile, Scytinium teretiusculum.

The maximum species number occurred in the middle part of the slope, that might be due its protection from cold winds. Moreover, in this part of the slope species with different ranges (arctic-alpine and boreal) can be found simultaneously.
In the study, area of $2000 \mathrm{~m}^{2}$ (0.20 ha) was examined using the sample plot method and 230 species of lichens and allied fungi were found within this area. As a result of study of lichen diversity along the linear route $(2 \mathrm{~km}) 190$ taxa were recorded. Moreover, 43 species were only found on the route (outside the sample plots), which is $16 \%$ of the total lichen species number in studied communities. For comparison: among the identified lichens of Olovgora Mountain, 214 species occurred on the permanent sample plots within the territory 0.44 ha. During the study of the this mountain by a walking method on the of route of length about $2 \mathrm{~km}$, just 9 species ( $4 \%$ of total species amount) were added to the list of lichens (Table 2). Obviously, the study of the lichen species composition by fixed sample plots makes it possible to obtain more complete information on the species diversity in the study area. However, to reveal the total species diversity, representative number of sample plots is required. Thus, the higher number of lichen species in Vysokaya Mountain (in comparison with Olovgora) founded by the route method, is explained by 2 times less area of sample plots in Vysokaya Mountain. This analysis emphasizes the importance of combining the two approaches to maximize the number of species detected per fixed area and obtained list closed to complete. The revealed diversity of lichen and allied fungi reflects the high species richness of studied rocky forest communities of Vysokaya Mountain.

At the present time, lichen diversity has been studied in rocky forest communities of three mountains of the Windy Belt Ridge - Olovgora (Tarasova et al., 2015), Muroigora (Tarasova et al., 2016) and Vysokaya, and the comparative analysis of species composition is presented for these surveyed territories (Table 2). The maximum number of species (273) was recorded for Vysokaya, the minimum (188) - for Muroigora. The relatively low lichen diversity in communities of Muroigora might be explained by significantly lower altitude, less time since last disturbance of communities, as well as smaller total area and area of surveyed rocky outcrops (Table 2). Nevertheless, in communities of Olovgora (the highest among the three studied mountains) was found 50 fewer lichen species than in Vysokaya, despite the long time since last disturbance of the communities and the larger surveyed area. 
Table 2. Lichen species diversity in studied rocky forest communities of mountains within the Windy Belt Ridge

\begin{tabular}{|c|c|c|c|c|c|}
\hline $\begin{array}{l}\text { Name of mountain } \\
\text { and location, height } \\
\text { above sea level } \\
\text { (m.a.s.l.) }\end{array}$ & $\begin{array}{l}\text { Area of rocky } \\
\text { outcrop/ studied } \\
\text { area, ha }+ \text { length } \\
\text { of route, } \mathrm{km}\end{array}$ & Type of communities & $\begin{array}{l}\text { Time since } \\
\text { disturbance, } \\
\text { yrs }\end{array}$ & $\begin{array}{l}\text { Number } \\
\text { of taxa }\end{array}$ & $\begin{array}{l}\text { Number of } \\
\text { specific taxa }\end{array}$ \\
\hline $\begin{array}{l}\text { Muroigora** } \\
63^{\circ} 34^{*} \mathrm{~N} 36^{\circ} 61^{\prime} \mathrm{E} \\
238 \mathrm{~m}\end{array}$ & $2.5 / 0.24+0$ & $\begin{array}{l}\text { Spruce, pine and mixed spruce-pine } \\
\text { forests, Vaccinium myrtillus-feather } \\
\text { mosses type }\end{array}$ & 172 & 188 & 15 \\
\hline $\begin{array}{l}\text { Olovgora* } \\
63^{\circ} 24^{\prime} \mathrm{N} 37^{\circ} 00^{\prime} \mathrm{E} \\
344 \mathrm{~m}\end{array}$ & $25 / 0.44+2$ & $\begin{array}{l}\text { Spruce forests of Vaccinium myrtil- } \\
\text { lus-feather mosses type }\end{array}$ & $>300$ & 223 & 37 \\
\hline $\begin{array}{l}\text { Vysokaya } \\
63^{\circ} 30^{\prime} \mathrm{N} 36^{\circ} 37^{\prime} \mathrm{E} \\
318 \mathrm{~m}\end{array}$ & $42.6 / 0.20+2$ & $\begin{array}{l}\text { Spruce forests of Vaccinium myrtil- } \\
\text { lus-feather mosses type }\end{array}$ & $>300$ & 273 & 74 \\
\hline \multicolumn{3}{|l|}{ Total species number } & & 343 & \\
\hline
\end{tabular}

Notes: *(Tarasova et al., 2015); **(Tarasova et al., 2016).

In comparison with Vysokaya Mountain, the total area of rocky outcrops in Olovgora is almost two times smaller, slopes are quite steep and the heterogeneity of the habitat conditions is less pronounced.

The slopes of Vysokaya Mountain are more diverse in terms of habitat conditions. The southwestern slope is steeper, while the northeastern slope has a more powerful soil layer, which increases the share of deciduous tree species, such as willow and aspen, in the tree stand. Variety of communities and substrates creates the bases for the formation of high lichen diversity on Vysokaya Mountain.

In total, 343 taxa of lichens and allied fungi have been found for the studied mountains of the Windy Belt Ridge (Tarasova et al., 2015; Tarasova et al., 2016). Of these, 131 species appear common species which are recorded on each mountain, while 129 species are specific, recorded on one of the mountains only. Both these species groups are represented in equal proportion $(38 \%)$ of the total species composition. Comparison of lichen species diversity of these mountains (Table 2) shows that the forests of high conservation value, the rocky communities with significant rocky outcrops in the form of faults, and landscape heterogeneity determine conditions for a high species diversity of lichens.

Nowadays, among the 560 species listed for the mainland of Arkhangelsk Region, 61\% were found in the communities of the three studied mountains of the Windy Belt Ridge.

As a conclusion, the Windy Belt Ridge is not only a unique geological object, but, according to our studies, it presents a combination of habitats with a rich potential for species diversity, in particular lichens, which still remains to be studied.

\section{ACKNOWLEDGEMENTS}

We would like to express our gratitude to the staff of Vodlozersky National Park (Viktor Mamontov, Maria Shreders, Vasily Ruchyovskih \& Sergei Zakutin) and Elena Churakova for help in organization of expedition in hard-to-reach localities. Orvo Vitikainen, Dmitry Himelbrant, Irina Stepanchikova, Gennadii Urbanavichus and Teuvo Ahti are thanked for assistance in the identification of some taxa, and consultations. We are grateful to reviewers for valuable corrections and recommendations, which have improved the quality of our work.

The study was supported by Ministry of Science and Higher Education of the Russian Federation (theme No. 0752-2020-0007), by RFBR (project number 20-04-00473), additional support was given by the Avrorin Polar-Alpine Botanical Garden-Institute of the Russian Academy of Sciences (institutional project No AAAAA18-118050490088-0, work by L. Konoreva), the N. Laverov Federal Center for Integrated Arctic 
Research of the Russian Academy of Sciences (project AAAA-A17-117122990042-2, work by A. Valekzhanin) and the Russian Foundation for Basic Research, RFBR (grant no. 18-05-60093, work by L. Konoreva).

\section{REFERENCES}

Alexeeva, N. 2005. Lichens from islands in the Russian part of the Gulf of Finland. Folia Cryptogamica Estonica 41: 5-12.

Andreeva, E. N., Bakkal, I. Ju., Gorshkov, V. V. et al. 2002. Methods of studying forest communities. Saint-Petersburg. 240 pp. (In Russian).

Brenner, M. 1886. Bidrag till kännedom af Finska vikens övegetation. IV. Hoglands lafvar. Meddelanden af Societas pro Fauna et Flora Fennica 13: 1-143.

Fadeeva, M. A., Golubkova, N. S., Vitikainen, O. \& Ahti, T. 2007. Conspectus of lichens and lichenicolous fungi of the Republic of Karelia. Petrozavodsk: Karelian Research Center of the Russian Academy of Sciences. 194 pp. (In Russian, English summary).

Gowan, S. P. \& Ahti, T. 1993. Status of the lichen genus Porpidia in eastern Fennoscandia. Annales Botanici Fennici 30: 53-75.

Hermansson, J. 2005. Ainoa mooreana new to Sweden. Graphis Scripta 17(2): 41-42.

Hermansson, J., Pystina, N. T. \& Kudrejasheva, D. I. 1998. Preliminary list of lichens of the Republic of Komi. Syktyvkar. 136 pp. (In Russian).

Himelbrant, D. E., Stepanchikova, I. S., Motiejūnaitė, J., Vondrak, J., Tagirdzhanova, G. M., Gagarina, L. V. \& Kuznetsova, E. S. 2015. New records of lichens and allied fungi from the Leningrad Region, Russia. VI. Folia Cryptogamica Estonica 52: 21-28. https:/ / doi.org/ 10.12697/fce.2015.52.03

GBIF Backbone Taxonomy. Accessed via https://www. gbif.org/ru/species/2600716 [24 August 2020]

Kuznetsova, E., Ahti, T. \& Himelbrant, D. 2007. Lichens and allied fungi of the Eastern Leningrad Region. Norrlinia 16: 1-62.

Konoreva, L. A., Frolov, I. V., \& Chesnokov, S. V. 2017. Lichens and allied fungi from the Pechenga district and surroundings (Lapponia Petsamoënsis, Murmansk Region, Russia). Folia Cryptogamica Estonica 54: 17-23. https://doi.org/10.12697/ fce.2017.54.04

Lavrinenko, O. V., Plusnin, S. N., Urbanavichus, G. P. \& Urbanavichene, I. N. 2005. Lichens of the mountain-tundra zone in the pechora-ilych reserve. Novosti Sistematiki Nizshikh Rastenii 38: 213-225.. (In Russian, English summary).
Melekhin, A. V. 2009. Lichens from Lapland Nature Reserve new to Russia and Murmansk region. Botanicheskii Zhurnal 94(2): 289-291 (In Russian).

Nordin, A., Moberg, R., Tønsberg, T., Vitikainen, O., Dalsätt, Å., Myrdal, M., Snitting, D. \& Ekman, S. 2011. Santesson's Checklist of Fennoscandian Lichen-forming and Lichenicolous Fungi. Ver. April 29, 2011 - http://130.238.83.220/santesson/ home.php (25 March 2020).

Orange, A., James, P. W. \& White, F. J. 2001. Microchemical methods for the identification of lichens. British Lichen Society, London. 101 pp.

Red Data Book of Arkhangelsk region. 2020. Arkhangelsk. 478 pp. (In Russian).

Red Data Book of the Russian Federation (plants and mushrooms). 2008. Moscow. 885 pp. (In Russian).

Stepanchikova, I. S., Himelbrant, D. E., \& Konoreva, L. A. 2014. The lichens and allied fungi of the Gladyshevskiy Protected Area (Saint Petersburg). Novosti Sistematiki Nizshikh Rastenii 48: 291-314. (In Russian, English summary). https://doi. org/10.31111/nsnr/2014.48.291

Tarasova, V. 2014. Platismatia norvegica - a new lichen record from European Russia. Folia Cryptogamica Estonica 51: 131-134. https://doi.org/10.12697/ fce.2014.51.15

Tarasova, V., Pystina, T., Androsova, V., Sonina, A., Valekzhanin, A. \& Konoreva, L. 2019. New records of lichens and allied fungi from Vodlozersky National Park within Arkhangelsk Region (NW Russia). Folia Cryptogamica Estonica 56: 87-98. https://doi.org/10.12697/fce.2019.56.09

Tarasova, V., Sonina, A., Androsova, V. \& Stepanchikova, I. 2015. The lichens of forest rocky communities of mountain Olovgora (Arkhangelsk Region, Northwest Russia). Folia Cryptogamica Estonica 52: 51-62. https://doi.org/10.12697/ fce.2015.52.07

Tarasova, V., Sonina, A., Androsova, V. \& Stepanchikova, I. 2016. The lichens of forest rocky communities of the hill Muroigora (Arkhangelsk Region, Northwest Russia). Folia Cryptogamica Estonica 53: 111-121. https://doi.org/10.12697/ fce.2016.53.13

Urbanavichus, G. P. 2010. A checklist of the lichen flora of Russia. St. Petersburg. 194 pp. (In Russian).

Urbanavichus, G., Ahti, T. \& Urbanavichene, I. 2008. Catalogue of lichens and allied fungi of Murmansk Region, Russia. Norrlinia 17: 1-80.

Urbanavichus, G., \& Urbanavichene, I. 2017. New records and noteworthy lichens and lichenicolous fungi from Pasvik Reserve, Murmansk Region, Russia. Folia Cryptogamica Estonica 54: 31-36. https://doi.org/10.12697/fce.2017.54.06 